\title{
A Low-complexity of VLC System using BPSK
}

\author{
https://doi.org/10.3991/ijes.v6i1.8072 \\ Trio Adiono $\left.{ }^{(}\right)$, Angga Pradana, Syifaul Fuada \\ Institut Teknologi Bandung, Indonesia \\ tadionolstei.itb.ac.id
}

\begin{abstract}
The design, implementation, and demonstration of visible light communication (VLC) system using Binary Phase Shift Keying (BPSK) modulation has been presented in this short paper. Our system is applied for indoor environment purpose. The test result shows that our VLC system able to work properly as expected, the BPSK constellation can be formed wirelessly through a visible light link. We obtained $13.4 \mathrm{kbps}$ of maximum data rate transfer.
\end{abstract}

Keywords-BPSK, Indoor application, VLC

\section{Introduction}

Nowadays, there is growing academic interest in visible light communication (VLC) studies. According to a report from [1], the scientific documents in 'Google scholar database' and 'IEEE Xplore digital library' are tend to increase in every year (from 2010 to 2015). We observe the research area of VLC in terms of indoor applications, it can be divided into several focuses including 1) the exploitation of hybridcommunication technologies, like hybrid RF-VLC, PLC-VLC, IR-VLC, and etc.; 2) indoor positioning system by light; 3) high-speed VLC system up to Tens of Gbps; 4) robust-VLC system against the optical influence, 5) modulation modeling, 6) reengineering design for low-complexity VLC system purpose and etc.

There are various modulations that employed for VLC system contains the digitaland analog-modulation [2], such as

- SCM-based (e.g. OOK, PWM, M-PAM, M-PPM, CAP, and etc.),

- Color-based (CSK and CIM), and

- OFDM-based with different mappers (e.g. BPSK, QPSK, QAM-16, QAM-64, and etc.).

The OFDM is the most popular technique for high-speed and efficient data transfer of VLC system. There are various types of OFDM [2], such as:

- DCO-OFDM,

- Inherent unipolar type (e.g. ACO-OFDM, PAM-DMT),

- Superposition OFDM type (eU-OFDM and LACO-OFDM),

- hybrid OFDM type (RPO-OFDM and HACO-OFDM), and etc. 
Associated with the modulation for VLC, in our previous work, we have been performed a VLC system with certain modulations, specifically a digital modulation: Pulse Width Modulation [3-6], Pulse Position Modulation [7], and the simplest modulation, OOK [8-10]. According to the comparison results among them, the mentioned modulations are wasteful in utilizing the available bandwidth, thus the communication speed is very limited [11]. One of the solutions is employed the multiplexing technique such as OFDM scheme to thrift the optical system's bandwidth [12].

In this work, we implement the simple OFDM scheme with Binary Phase Shift Keying (BPSK) mapper. The BPSK was chosen because of the most powerful of all types of PSK. It takes the highest distortion level to make the demodulator perform the wrong decision. The rest of this paper has been organized as follows, second section discusses the methodology. Third section looks to the successful demonstration. The last part is closed by fourth Section, that is conclusions and references.

\section{Methodology}

\subsection{Modulation Design}

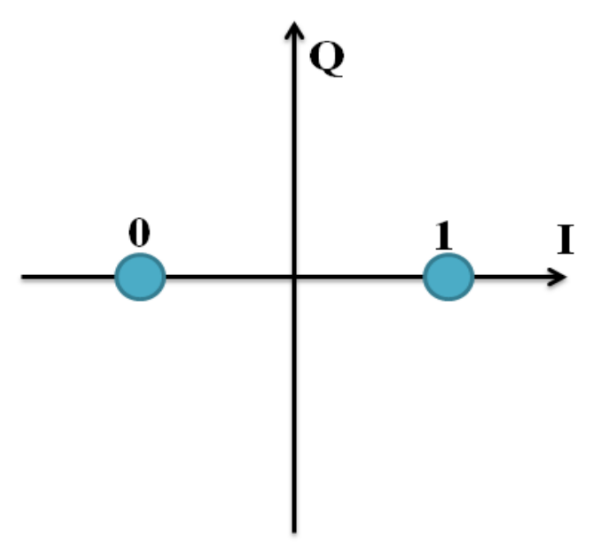

(a)

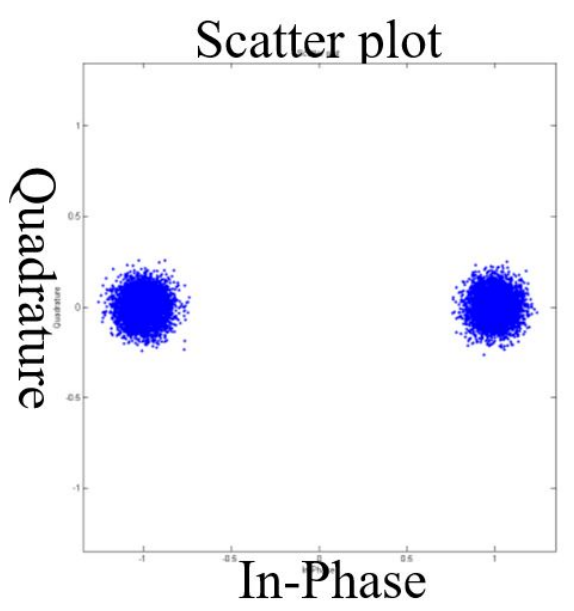

(b)

Fig. 1. Constellation diagram for gray-coded BPSK: (a) an illustration, reproduced from [13]; (b) simulation in MATLAB with signal-to-noise ratio $(\mathrm{SNR})=20 \mathrm{~dB}$

BPSK only uses two separate phases as far as $180^{\circ}$, so it can be called as 2-PSK. The determination of the point location in constellation diagram is free anywhere. However, it must with a specific requirement that the two points are separated as far as $180^{\circ}$. Fig. 1(a) shows the two points are located on the real axis (at $0^{\circ}$ and $180^{\circ}$ ). In BPSK modulation, the signal is reflected in two possibilities: signal ' 1 ' is represented by giving a phase-shift of a carrier signal with $0^{\circ}$. Whereas the signal ' 0 ' is represented by shifting the signal phase carrier with $180^{\circ}$. Fig. 1(b) depicts the simulation of 
BPSK in MATLAB. The BPSK is only able to modulate ' 1 bit' per symbol so it is not suitable for high-speed data rate applications.

\subsection{Analog Front-End Design}

Fig. 2 depicts the whole system of our VLC system. The USB is employed to connect the computer to the VLC module. The microcontroller STM32F4 was chosen as the main controller. We used components with a low-cost factor in order to meet the low-complexity requirement of VLC system. The antenna is utilized a commercially white LED while the PIN photodiode was employed as a photo-sensor.

As shown in Fig. 2, the physical layer of our VLC system contains a low-cost Bias$\mathrm{T}$ and analog front-end receiver that has been realized by Op-Amps configuration. The Bias-T blocks consist of gain buffer, voltage reference circuit, DC-offset adder, and current amplifier. We discuss the design and implementation of Bias-T clearly in [14-18]. While the receiver blocks consist of TIA circuit [19-21], Pre-Amp, DC-offset adjuster with auto and manual mode, analog filter [22-24], and automatic gain controller circuit [25-26].

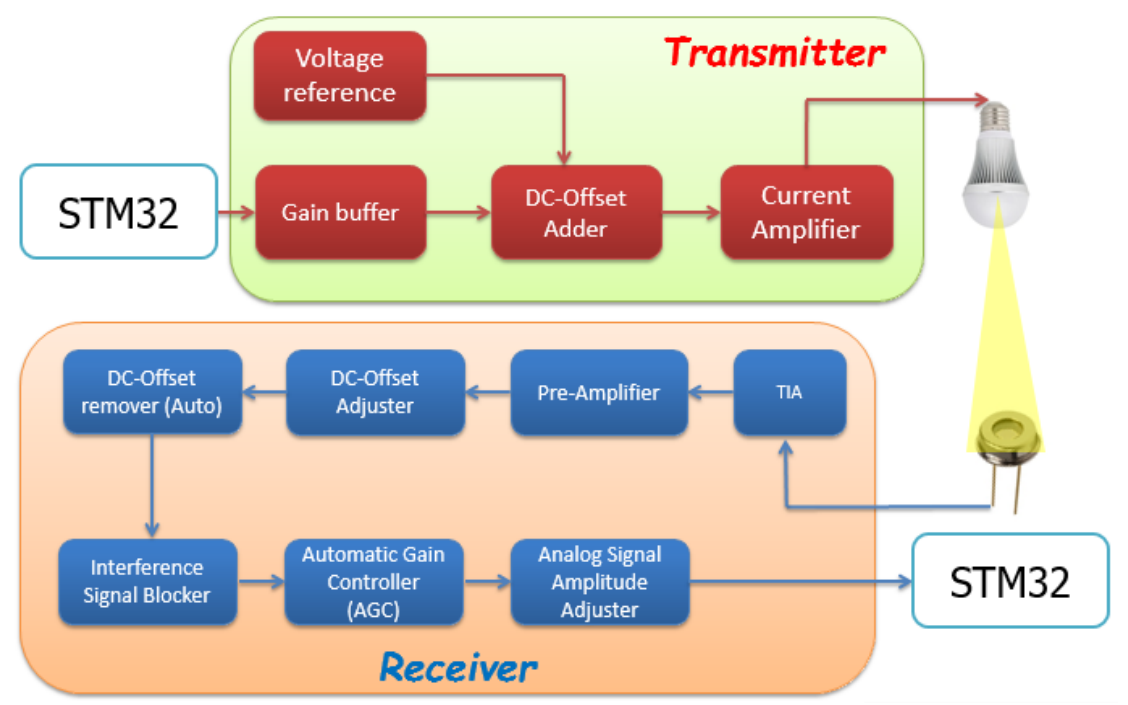

Fig. 2. The VLC transceiver blocks

\section{$3 \quad$ Results}

Fig. 3(a) visualizes the demonstration of our VLC system using BPSK modulation in which the parameters for testing are referred to Table 1 . It contains of seven variables (i.e. LED, Photodiode, channels setting, topology of link used, the environment condition of the performance test, initial optical angle, and distance of channel). There are 2 computers used for displaying the transmitted and received BPSK signal. 
Based on the performance test as shown in Fig. 3(b), we can conclude that the BPSK constellations can be formed through visible light link. However, those constellations that viewed from Fig. 3(b) are too small, thus we zoomed-out the achieved data as depicted in Fig. 4 for various distances of the optical channel. It can be concluded that the longer optical distance the higher error at receiver. The optical distance is about $50 \mathrm{~cm}$ for the best option.

The user interface was developed by the Delphi 7.0 software which is installed in PC transmitter as well as PC receiver. In summary, we obtained $13.4 \mathrm{kbps}$ of data rate, this is the maximum speed transfer using BPSK modulation. The measurement methodology of available bandwidth and its SNR are discussed in separate papers (Please see the following references [28-29]). While the obtained bit rate and bit-error rate (BER) are discussed in [30-31].

Table 1. Parameters of VLC demo

\begin{tabular}{|l|l|}
\hline \multicolumn{1}{|c|}{ Parameters } & \multicolumn{1}{c|}{ Information } \\
\hline LED & $\begin{array}{l}\text { Model: Hyrite Coochip® LEDMD-W110C } \\
\text { Color: Cool white } \\
\text { Type: Phosphorus }(p \text { LED) } \\
\text { LED Power: 9 Watts }\end{array}$ \\
\hline Photodiode & $\begin{array}{l}\text { Model: KODENSHI SP-8ML [27] } \\
\text { Type: PIN photodiode } \\
\text { Short current: 270 } \mu \text { A } @ 1000 \text { Lux }\end{array}$ \\
\hline Channels & Directed Line-of-sight (LoS) \\
\hline Link topology & Point-to-point communication \\
\hline Test condition & Dark \\
\hline Optical angle & Ideally $0^{\circ}$ \\
\hline Optical channel distance & To be varied \\
\hline
\end{tabular}

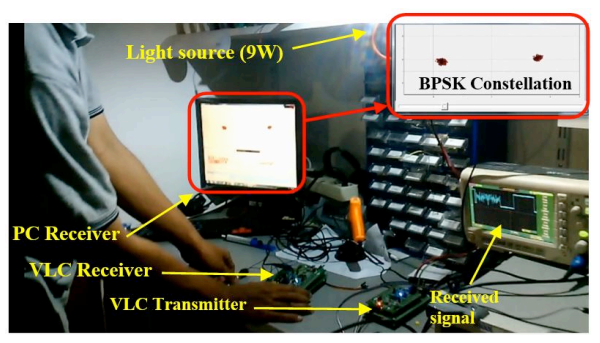

(a)

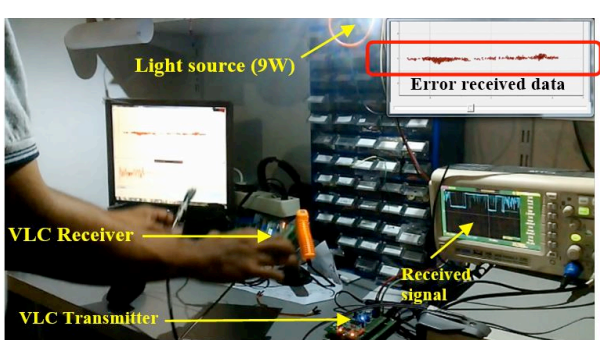

(b)

Fig. 3. Demonstration of VLC system based on DCO-OFDM (BPSK mapper): (a) real-time constellation using BPSK at ideal distance; (b) A photograph of experiment when the angle of reception was changed shorter/longer. Documented by S. Fuada \& A. Pradana $\mathbb{0} 2016$. 


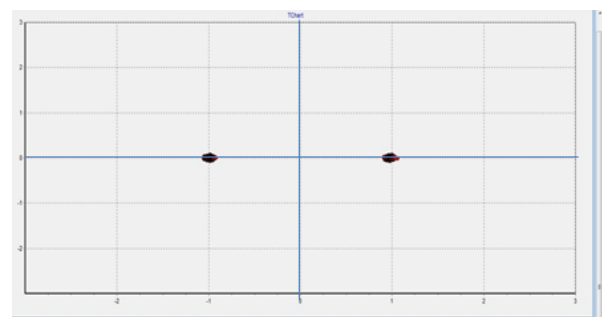

(a)

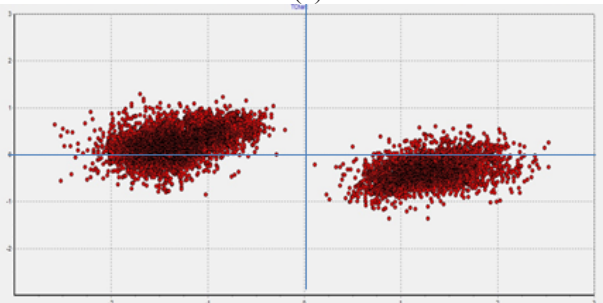

(c)

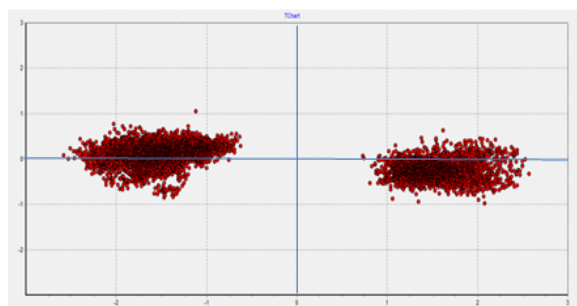

(b)

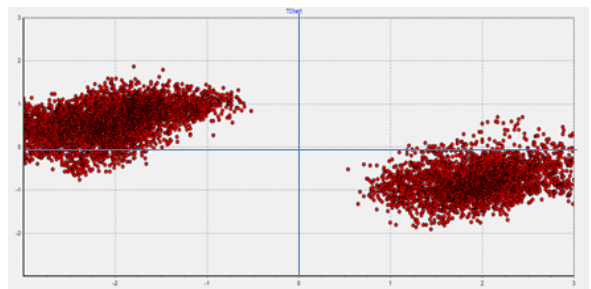

(d)

Fig. 4. Constellation of BPSK mapper for: (a) $50 \mathrm{~cm}$; (b) $75 \mathrm{~cm}$; (c) $100 \mathrm{~cm}$; (d) $130 \mathrm{~cm}$ of optical channel (the distance between VLC transmitter to the VLC receiver)

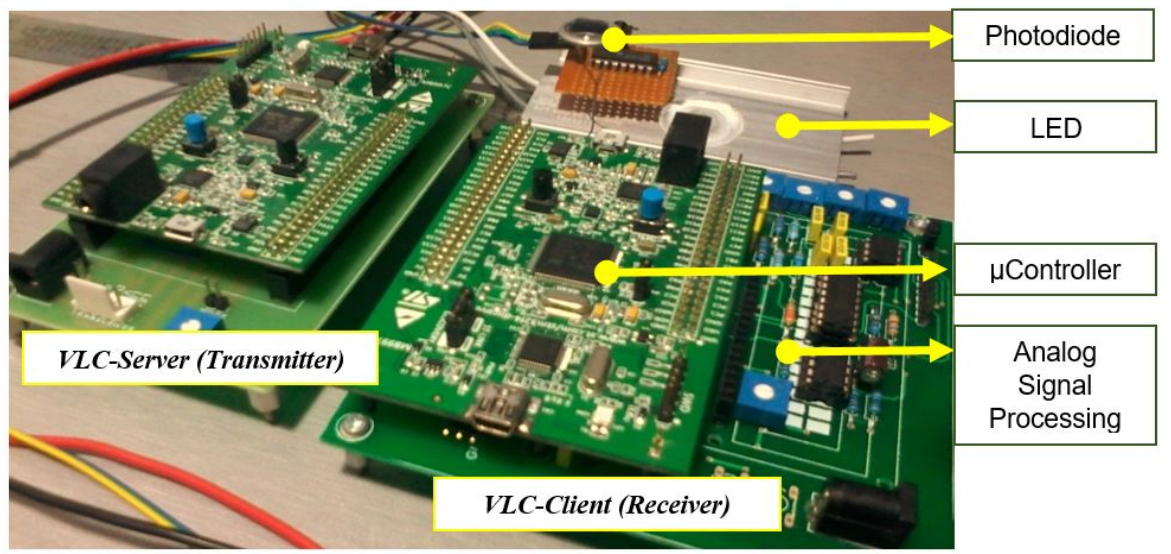

Fig. 5. The Hardware of low-complexity VLC system consisting transmitter (Bias-T circuit and Microcontroller Tx) and receiver module (Analog receiver and Microcontroller Rx), retrieved and fully edited from [11] with permission

\section{Conclusions}

In line with performance test, it can be summarized that the designed BPSK can met the qualification of with the related theories. Our VLC system can perform properly with optical distance up to $40 \mathrm{~cm}$. We carefully designed our system to great deal with low-complexity target. Using BPSK modulation, we obtained the maximum bitrate of $\sim 13.4 \mathrm{kbps}$. This work is part of Master thesis that can be found in [11]. 


\section{Acknowledgment}

This research is one part of the big project entitled "Machine-to-machine Communication (M2M) based on Visible Light Communication (VLC)". It was funded by the Ministry of Research, Technology and Higher Education of the Republic Indonesia via Kerjasama Luar Negeri (KLN) scheme collaborated with Pukyong National University, Republic of South Korea (No. 009/SP2H/LT/DRPM/IV/2017).

\section{References}

[1] M. Figueiredo, et al., "Lighting the wireless world: the promise and challenges of visible light communication," IEEE Magz. October 2017.

[2] M.S. Islim and H. Haas, "Modulation Techniques for Li-Fi," ZTE Communications, Vol.14(2), pp. 29-40, April 2016.

[3] A. Pradana, et al, "Design and Implementation of Visible Light Communication System using Pulse Width Modulation," Proc. of the $5^{\text {th }}$ ICEEI, pp. 25-30, August 2015. https://doi.org/10.1109/ICEEI.2015.7352464

[4] T. Adiono, S. Fuada, and A. Pradana, "Desain dan Realisasi Sistem Komunikasi Cahaya Tampak untuk Streaming Teks berbasis PWM," J. Setrum, Vol. 6(2), pp. 270-279, Desember 2017.

[5] A. Pradana, S. Fuada, and T. Adiono, "Desain dan Implementasi Sistem Visible Light Communication berbasis Pulse Width Modulation," Unpublished.

[6] T. Adiono, A. Pradana, and S. Fuada "Rancang Bangun Sistem Komunikasi Cahaya Tampak dengan Modulasi 2-PWM berbasis Mikrokontroller," Unpublished.

[7] A. Pradana, et al. "VLC Physical Layer Design based on Pulse Modulation (PPM) for Stable Illumination," Proc. of ISPACS. pp. 368-373. November 2015.

[8] T. Adiono, R.A. Saputro, M. Lutfi, and S. Fuada, "A real-time wireless video streaming based on VLC Technology using FPGA," Unpublished.

[9] T. Adiono, R.A. Saputro, M. Luthfi, and S. Fuada, "FPGA Implementation for Real-time File Transfer using Visible Light Communications," Unpublished.

[10] T. Adiono, et al., "Visible light communication system for wearable patient monitoring device," Proc.of TENCON, November 2016. https://doi.org/10.1109/TENCON.2016.7848 367

[11] A. Pradana, "Rancang bangun layer fisik komunikasi cahaya tampak berbasis DC-OFDM dan PWM," Master thesis, ITB, 2016.

[12] T. Adiono, Yulian Y. Aska, A.A. Purwita, S. Fuada, and A.P. Putra. "Modeling OFDM system with Viterbi Decoder Based Visible Light Communication," Proc. of ICEIC, January 2017.

[13] Anonymous, "Comparison of 8-QAM, 16-QAM, 32-QAM, 64-QAM 128-QAM, 256QAM," Available at: www.electronics.com/info/rf-technology-design/quadratureamplitudemodulation-qam/8qam-16qam-32qam-64qam-128qam-256qam.php.

[14] S. Fuada, T. Adiono, A. P. Putra, and Y. Aska, "A Low-cost Analog Front-End (AFE) Transmitter Designs for OFDM Visible Light Communications," Proc. of the IEEE Int. Symposium on Electronics and Smart Devices (ISESD), pp. 371-375, October 2016. https://doi.org/10.1109/ISESD.2016.7886750

[15] T.Adiono and S. Fuada, "Desain dan Implementasi LED Driver Linier untuk Aplikasi Visible Light Communication," Unpublished. 
[16] T. Adiono and S. Fuada, "Prototyping Design of Low Cost Bias-T Circuit based-on OpAmp for Visible Light Communication," Unpublished.

[17] S. Fuada, and T. Adiono, "Rancang Bangun Layer Fisik Visible Light Communication Pada Sistem Transmisi Audio," J. INFOTEL, Vol. 9(3), pp. 352-360, August 2017. https://doi.org/10.20895/infotel.v9i3.288.

[18] S. Fuada, T. Adiono, A.P. Putra, Y. Aska, "LED Driver Design for Indoor Lighting and Low-rate Data Transmission Purpose, Optik-Int. J. for Light and Electron Optics, Vol. 156, pp. 847-856, 2017, https://doi.org/10.1016/j.ijleo.2017.11.180.

[19] S. Fuada, A.P. Putra, Y. Aska, and T. Adiono, "Trans-impedance Amplifier (TIA) Design for Visible Light Communication (VLC) using Commercially Available OP-AMP," Proc. of the $3^{\text {rd }}$ Int. Conf. on Information Tech. Computer, and Electrical Engineering (ICITACEE), pp. 31-35, October 2016. https://doi.org/10.1109/ICITACEE.2016.7892405

[20] S. Fuada, T. Adiono, A.P. Putra, and Y. Aska, "Noise Analysis in VLC Optical Link based Discrette OP-AMP Trans-Impedance Amplifier (TIA)," Jurnal of TELKOMNIKA, Vol. 15(3), pp. 1012-1021, September 2017. https://doi.org/10.1109/ICITACEE.2016.7892405

[21] S. Fuada, A.P. Putra, Y. Aska, and T. Adiono, "Noise Analysis of Trans-impedance Amplifier (TIA) in Variety Op Amp for use in Visible Light Communication (VLC) System," International Journal of Electrical and Computer Engineering (IJECE), Vol. 8(1), 2018

[22] T. Adiono, A. Pradana, R.V.W. Putra, and S. Fuada, "Analog Filters Design in VLC Ana$\log$ Front-End Receiver for Reducing Indoor Ambient Light Noise," Proc. of the IEEE Asia Pacific Conf. on Circuit and Systems (APCCAS), pp. 581-584, October 2016. https://doi.org/10.1109/APCCAS.2016.7804058

[23] T. Adiono, and S. Fuada, "Optical Interference Noise Filtering over Visible Light Communication System Utilizing Analog High-Pass Filter Circuit," Proc. of the 2017 Int. Symp. on Nonlinear Theory and Its Applications (NOLTA), pp. 616-619, December 2017.

[24] S. Fuada, A.P. Putra, Y. Aska and T. Adiono, "A First Approach to Design Mobility Function and Noise Filter in VLC System Utilizing Low-cost Analog Circuits," Int. J. of Recent Contributions from Engineering, Science, and IT (iJES), Vol. 5(2), pp. 14 - 30, 2017. https://doi.org/10.3991/ijes.v5i2.6700

[25] T. Adiono, S. Fuada, and R.A. Saputro, "Automatic Gain Control Circuit for Mobility Visible Light Communication System using LM13700" Proc. of the IEEE Int. Symposium on Electronics and Smart Devices (ISESD), Yogyakarta, Indonesia, October 2017.

[26] T. Adiono, A. Pradana, and S. Fuada, "Employing LM13700 as AGC for Mobile Visible Light Communication System,"Unpublished.

[27] T. Adiono and S. Fuada, "Karakteristik PIN Photodiode KODENSHI SP-8ML untuk Aplikasi Visible Light Communication," Unpublished.

[28] S. Fuada, "Design and Implementation of Analog Front-End Transceiver Module for Visible Light Communication System," M.T. thesis, Dept. Elect. Eng., School of Electrical Engineering and Informatics, Institut Teknologi Bandung, Bandung, Indonesia, 2017.

[29] T. Adiono, S. Fuada, and S. Harimurti, "Bandwidth Budget Analysis for Visible Light Communication Systems utilizing Commercially Available Components," Proc. of the $10^{\text {th }}$ Int. Conf. on Electrical and Electronics Engineering (ELECO), pp. 1375-1380, December 2017.

[30] T. Adiono, A. Pradana, and S. Fuada, "A Low-Cost Hardware Implementation for QAM16 Visible Light Communications," Unpublished.

[31] T. Adiono, A. Pradana, and S. Fuada, "Visible Light Communications System using Quadrature Phase-Shift Keying," Unpublished. 


\section{$7 \quad$ Authors}

Trio Adiono is a senior lecturer of the School of Electrical Engineering and Informatics ITB. He is a member of international conferences (e.g. GCCE, ISPACS, APSIPA, ISESD), a head director of University Center of Excellence on Microelectronics, Institut Teknologi Bandung, Indonesia and a chairman of Solid-State Circuits Society (SSCS) Indonesia chapter.

Angga Pradana achieved his B.Eng degree in Institut Teknologi Sepuluh Nopember Surabaya in 2013 and M.Sc degree in Institut Teknologi Bandung, Indonesia in 2016. His research interest include Visible light communication system, robotics and artificial intelligence, DSP, instrumentation and discrete analog design.

Syifaul Fuada achieved his B.A. degree in Universitas Negeri Malang in 2014 and M.Sc degree in Institut Teknologi Bandung, Indonesia. He was with the University Center of Excellence on Microelectronics ITB since 2016. His research interests include visible light communication system, DSP, IC design, multimedia learning development, instrumentation and discrete analog design.

Article submitted 11 December 2017. Resubmitted 02 February 2018. Final acceptance 23 February 2018. Final version published as submitted by the authors. 